\title{
The Practice of Knowledge Management Processes- A Comparative Study of Public and Private Higher Education Institutions in Udupi \& South Kanara Districts
}

\author{
Madhukara Nayak $^{1}$, Augustine B V Barboza ${ }^{2}$,U.SAI KRISHNA ${ }^{3}$ \\ [1], [2], [3] Manipal Institute of Technology (A Constituent of Manipal University), Manipal, India.
}

\begin{abstract}
Knowledge is one of the most important driving forces for business success. Higher Educational Institutions (HEIs) are becoming more knowledge intensive and in the global market they are aware of this, and try to explore the field of knowledge management (KM) in order to improve and sustain their competitiveness. HEIs create and apply knowledge in their processes and activities. The growth in the number of private HEIs in India, in the last decade, has multiplied and hence it has increased the competition and the pressures for performing better. The institutions are forced to recognize the need for knowledge management (KM) practices. The objective of this research work is to investigate and compare the practices of knowledge management processes (knowledge creation, capture, organization, storage, dissemination and application) in both public and private HEIs in Udupi and South Kanara districts. The methodology used in this research is based on Lawson's (2003) model. The variables used for comparing the practices of knowledge management process in public (NITK) and private (MIT) HEIs in Udupi and South Kanara districts are Knowledge creation, capture, organisation, storage, dissemination, and application. The target population of the research is consisting of all faculty members in these two HEIs (N=782). The Sample size was estimated about 201 people based on Morgan's table. A questionnaire, which was applied lesson's theory, was used to assemble the needed data, and the SPSS software was used for analysing the data. The results showed no significant differences among the knowledge creation, knowledge capturing, organizing and application in both HEIs. And there is a significant difference among knowledge storing, dissemination and KM effectiveness in both the HEIs.
\end{abstract}

Keywords: Knowledge management, Private education, Public education, HEI, SPSS.

\section{Introduction}

There is a consensus between the resource-and the knowledge-based views that the firms are seeking to maintain competitive advantage by exploiting and leveraging knowledge for value creation purposes. According to the resource-based view the only way to achieve competitive advantage is through the strategic use of scarce, intangible, and firm-specific resources that include knowledge. Here Knowledge has been stressed as the most eminent factor as viewed from the knowledge-based perspective. Hence the business sector have advanced to equip themselves with the ability of managing knowledge to stand competition strategically, to overcome problems swiftly and to capitalise on the opportunities as they emerge.

Similarly, the higher education institutions (HEIs), just like the private concerns, see the need to gain competitive edge due to stiff competition and pressure to face globalisation. Hence many HEIs have gone global with the intention to recruit the international students to the country.

There are three reasons why the knowledge management (KM) is imperative to the HEIs. First and foremost is that the HEIs by nature are knowledge-intensive organisations and they are recognised to be in the knowledge business since knowledge production, distribution and application are ingrained in them. Knowledge, in this case, is both a HEI's main production factor and its final product.

Second, the unprecedented growth of HEIs, in which the number has gone more than doubled after 1996, compelled with the increasing intakes by the institutions, both public and private, have driven stiff competition among them for academics and students, both within the country and abroad.

Third, the recent issues of the quality of courses offered by the various HEIs have been very important to the nation. By considering both the resource- and knowledge-based views, proper management of knowledge can act as a strategic tool for these HEIs to remain and/or gain the competitive advantage

Hence, the KM, which has been long established in business, must also be established in the education sector as society moves from the industrial to the knowledge age to improve teaching -learning, and to provide a strong knowledge base for research-based practices and strategies. There is so much need for KM in education as it is there in industries. The HEIs are suitable places to apply KM practices in order to support their functional and operational processes. This is because HEIs are supposed to profit greatly from the development and application of certain KM mechanisms that assist in identifying not only what is known, but also what must be known, similar to any business organisation. 
Hence, it is obvious that the public and the private HEIs have much to gain from KM implementation. However, there is a deliberation that the sector is a better manager of knowledge. The Literature on the private education discusses that the private universities or colleges are likely to develop the quality of provision by increasing the competition amongst the educational providers (both public and private). The major advantage of the private sector HEIs has been providing the type of education that is in demand, and the graduates typically experience the lower unemployment rates, and get better-paid jobs. On the other hand, the public HEIs provide greater quality of education because they are well established and strongly supported by their research and development activities. However, they may be slow in responding to the fast demands of the market. Hence, when the knowledge is HEIs' main business, the private and public HEIs manage it differently to project their own speciality warrants research.

There have been many studies carried out to propose the implementation of the KM processes in business areas and even some in HEIs, and very few have attempted to test them empirically especially the differences in practices of KM processes between public and private HEIs. Most of the studies on the KM processes have been conducted on for-profit organisations and the results may be biased towards these firms. As the KM processes are well grounded, it is timely to assess them empirically in the HEIs' setting. Since the KM requires significant investments of time, money and personnel, a careful investigation of the KM processes can determine the success of the implementation of KM in the HEIs.

The higher education institutes create knowledge during their academic and administrative processes. Knowledge is created as explicit knowledge in the form of documents, procedures, results and the tacit knowledge in the form of experiences, judgements, views and perceptions that resides with the individuals. But the challenge is how to make this explicit and tacit knowledge available to the institution as an integrated central resource. Capturing the institutional knowledge and making it available ensures continuity and accelerates the Institutional learning. On the other hand, most of HEIs face the difficult task of integrating their institutional knowledge for improved knowledge sharing and, in effect, decision making. Actually, Knowledge is created at various levels in different forms and is required at each level in a different form. Academic and administrative processes of teaching, examination, evaluation, admissions, analysis, training and placement and research and consultancy result in many useful experiences and studies which may be defined as knowledge in the context of higher educational institutes. The KM in higher educational institutions aims at integrating the knowledge made at all levels and using it for the institute's goals and objectives. This may have the effects in improving the operational quality, capacity development and effectiveness of the organization leading to improved productivity and performance. An academic institution is made up of a number of components or levels containing faculty, students, administration, academics, research and training and placement. Each of these stages will create knowledge and consumes knowledge, though the nature of knowledge varies at each level. It is important to identify the knowledge that contributes at each level to the system and the knowledge that requires at each level to perform its functions, and find ways to apply this knowledge effectively at each point of use. A robust KM system must stick to the information needs of all the levels.

Every organization is a store of knowledge and the problem is that it is maintained by the people. Sometimes they may be busy with their work or may leave the organization. So it is better to capture this knowledge and make available to others. Typically, organization would be using the past data and information derived from it, for predicting the future development. On the available information, your number of other factors, such as your past experience, advice from experts based on their experience etc. as the organization grows in size and complexity; it may not be that easy to identify the experts. Also the experts may not always be available to provide his/ her insight. It does not mean that the organizations have to forego maximum use of the knowledge maintained the expert. The answer to this is knowledge management. The Knowledge management basically deals with the ways and means of capturing and making available knowledge of the experts to others, in the electronics form. Another aim of knowledge Management is to capture the knowledge maintained by the employees and share it with others and across the organization.

Higher education is of great importance in developing countries, since it helps students to develop into elites and take advantage of information technology. More details can be found in various research articles published in various journals, books, conference proceedings, etc[1-13]

\section{Research Objectives}

To examine the respondents' knowledge of KM;

$>$ To identify the level of practices of KM processes in private and public HEIs; and

$>$ To compare the level of practices of KM processes between private and public HEIs. 


\subsection{Introduction}

\section{Methodology}

Methodology used for collecting and analysing the data. The conceptual model for measuring the knowledge management effectiveness for the public and the private HEIs in Udupi and Dakshina Kannada districts. The data collection methods adapted, the sample size, sampling technique, target population, pilot study, development of survey instrument, validation of survey instrument have been discussed in this paper. Various hypotheses that are developed and the various statistical tools used in conducting the tests are also discussed in this paper.

\subsubsection{Sampling}

The unit of analysis for this study is the HEIs divided into two strata: public and private. The criteria for selecting the HEIs are, first, the nature of the institutions is engineering colleges. The HEIs chosen for this study have been upgraded to full university status. However, since, in essence, they remain the same faculty wise and in physical and administrative structure, they have been retained as units of analysis. Within each stratum, the elements, i.e. academics, have been surveyed. The academics have been chosen because of their responsibility in generating knowledge through research and disseminating knowledge via teaching. Moreover, the academics are the ones who faced lot of pressure to produce results from educational reform efforts, which in turn results in more practitioner-based research initiatives.

The first measure taken was to contact the public and private HEIs in Udupi and Dakshina Kannada districts. The private HEI is the Manipal Institute of Technology Manipal, and the public HEI is the NITK, Surathkal. The Questionnaires were distributed personally to all the academics in the public and private HEIs so as to ensure a maximum return rate of the questionnaires. Actually a total sample of 200 respondents would be sufficient. But in this study 289 samples have been used, which is more than the requirements.

\subsection{Sampling Design}

\subsubsection{Target Population}

The target population in the research is focused on the academics of MIT, Manipal and NITK, Surathkal. The total number of teaching faculty (Professors, Associate Professors, and Assistant Professors) in these institutes is 782 .

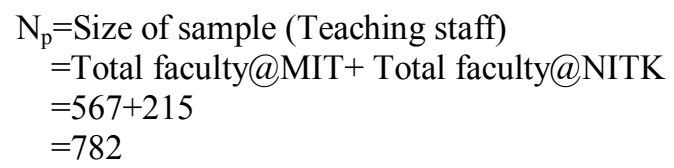

\subsubsection{Sampling Size}

The sample size is calculated using the following formula (C.S Kothari (1990) Research methodology) $\mathrm{n}=\left(\mathrm{Z}^{2} * \mathrm{p} * \mathrm{q} * \mathrm{~Np}\right) /\left(\mathrm{e}^{2}(\mathrm{~Np}-1)+\left(\mathrm{Z}^{2} * \mathrm{p} * \mathrm{q}\right)\right)$

$\mathrm{p}=$ Proportion of the defects in the universe ( $2 \%$ defect is assumed)

$\mathrm{q}=(1-\mathrm{p})$

$\mathrm{z}=1.96$ (as per table of scores in normal distribution within selected range of $\mathrm{z}$ for a confidence level of $95 \%$ )

$\mathrm{e}=$ Acceptable error (an error $2 \%$ of the true value is assumed)

$\mathrm{n}=200$ (Minimum sample size)

\subsection{Smart PLS}

The software application for Partial Least Squares Structural Equation Modeling (PLS-SEM) is Smart PLS. It was developed by Ringle, Wende \& Will (2005). It is used by many researchers and marketers for data analysis and to prioritize the resources.

\subsection{SPSS (Statistical Package for the Social Sciences)}

SPSS is a software used for statistical analysis and is acquired by IBM. It will perform a variety of statistical procedures. Data manipulation, performing of statistical techniques varying from means to regression and drawing of graphs can be done using SPSS. One can read different types of data files such as excel and csv in SPSS.

\section{Result Analysis}


The final outcomes of the research work show the relationship between the practices of knowledge management in public and private higher education institution. The independent sample $\mathrm{T}$ test is been conducted and the results are shown below.

\subsubsection{Questionnaire}

Self-reporting standard questionnaire was used as the main form of data collection. The questionnaire is divided into two sections to specifically address the three objectives determined in this study. Section 1 contains two questions measuring the respondents' knowledge of KM and whether they are aware that their institution has a formal KM programme in place. Section 2 contains 23 statements measuring the KM processes. The questions were adapted from the KM Assessment Instrument (KMAI) developed by Lawson (2003), utilising a five-point Likert scale ranging from 1 strongly disagrees to 5 strongly agrees.

This research uses quantitative data and quantitative analyses and has been carried out using the Statistical package for social sciences (SPSS) software version 20. The study also tested the reliability of the survey instrument so that the desired and valid results are obtained. For this the Cronbach's Alpha has been used. Descriptive statistics like mean and standard deviation have been used for the analyses. To establish relationships between the variables of practices KM between the private (MIT) and the public (NITK) higher education institutions the Independent Sample T test has been used to test the hypotheses.

\subsection{Validation of survey instruments}

\subsubsection{Pilot Study}

The Pilot study has been carried out with a sample size of 30 respondents collected from MIT through direct interaction. Data had been entered in the Excel sheet using SPSS software and Smart PLS was used to perform the factor analysis. The quality criteria had been checked by calculating the AVE, composite reliability, $\mathrm{R}$ square, Cronbach's Alpha and latent variable correlation values were calculated.

\subsubsection{Descriptive analysis}

When the survey was conducted, the total respondents were 289. There were 155 respondents from MIT, Manipal and 134 from NITK, Surathkal. Out of 289 respondents, the total number of Professors who responded to the survey from the two institutes was 11, Associate professors 47, Assistant professors 231. The number of female respondents was 41 and the male respondents were 248 . The respondents who had their age limit less than 30 years were 47, between 31 to 45 years were 199, and above 45 years were 43 .

Table 1: Descriptive Statistics

\begin{tabular}{|l|c|c|}
\hline & $\mathrm{N}$ & Std. Deviation \\
\hline Age of employees & 289 & .559 \\
\hline Gender of employees & 289 & .350 \\
\hline Designation & 289 & .509 \\
\hline Type of institute & 289 & .500 \\
\hline Valid N (list wise) & 289 & \\
\hline
\end{tabular}

Table2: Age Of Employees

\begin{tabular}{|c|c|c|c|}
\hline \multicolumn{2}{|c|}{} & Frequency & Percent \\
\hline \multirow{3}{*}{} & & 47 & 16.3 \\
\cline { 2 - 4 } & & 199 & 68.9 \\
\cline { 2 - 4 } & Valid & Below 30 & 14.9 \\
\cline { 2 - 4 } & & Bet 31-45 & 100.0 \\
\hline
\end{tabular}

Table 3: Gender of Employees

\begin{tabular}{|c|c|c|c|}
\hline \multicolumn{2}{|c|}{} & Frequency & Percent \\
\hline Valid & Male & 248 & 85.8 \\
\cline { 2 - 4 } & & & \\
\cline { 2 - 4 } & Female & 41 & 14.2 \\
\cline { 2 - 4 } & & & 100.0 \\
\cline { 2 - 4 } & Total & 289 & \\
\hline
\end{tabular}

Table4: Designation

\begin{tabular}{|c|c|c|c|}
\hline \multicolumn{2}{|c|}{} & Frequency & Percent \\
\hline Valid & Professor & 11 & 3.8 \\
\cline { 2 - 4 } & Associate Prof & 47 & 16.3 \\
\cline { 2 - 4 } & Assistant Prof & 231 & 79.9 \\
\cline { 2 - 4 } & Total & 289 & 100.0 \\
\hline
\end{tabular}

Table 5: Type Of Institute

\begin{tabular}{|l|l|} 
Frequency & Percent \\
\hline
\end{tabular}


Independent sample $\mathbf{T}$ test

\begin{tabular}{|l|l|c|c|}
\hline Valid & Private & 155 & 53.6 \\
\cline { 2 - 4 } & Government & 134 & 46.4 \\
\cline { 2 - 4 } & Total & 289 & 100.0 \\
\hline
\end{tabular}

Assumption:

- The two groups are independent

- The population follows a normal distribution

- The variances in group are equal

$\mathbf{H}_{\mathbf{0}}$ : The variances are equal

$\mathbf{H}_{\mathbf{a}}$ : The variances are not equal

Check if sig $<0.005$

If yes $=$ consider equal variance (sig. 2 tailed)

If no $=$ consider unequal variance (sig. 2 tailed)

Table 6: Significant Value

\begin{tabular}{|l|c|c|}
\hline \multicolumn{1}{|c|}{ practices } & Sig.(2 tailed) & Hypothesis \\
\hline Knowledge creating & 0.247 & Accept $\mathrm{H} 1_{0}$ \\
Knowledge organizing & 0.403 & Accept $\mathrm{H} 2_{0}$ \\
Knowledge capturing & 0.675 & Accept $\mathrm{H} 3_{0}$ \\
Knowledge storing & $0.000^{* *}$ & Accept $\mathrm{H} 4 \mathrm{a}$ \\
Knowledge disseminating & $0.003^{* *}$ & Accept H5a \\
Knowledge application & & \\
KM effectiveness & 0.736 & Accept $\mathrm{H} 6_{0}$ \\
& $0.011^{*}$ & Accept $\mathrm{H} 7 \mathrm{a}$ \\
\hline
\end{tabular}

$\mathbf{H}_{\mathbf{0}}$ : There is no significant difference between the Knowledge practices of private \& public higher education institution.

$\mathbf{H}_{\mathrm{a}}$ : There is a significant difference between the Knowledge practices of private \& public higher education institution.

Table 7: Mean Value

\begin{tabular}{|l|c|c|}
\hline & Mean (private) & Mean (government) \\
\hline Knowledge storing & 3.9496 & 4.5226 \\
Knowledge disseminating & 4.2817 & 4.4839 \\
KM effectiveness & 4.3109 & 4.5054 \\
\hline
\end{tabular}

$\underline{\text { Knowledge creation }}$

Table 8: Results Of Independent Sample T Test- Knowledge Creation

\begin{tabular}{|c|c|c|c|c|c|}
\hline $\begin{array}{c}\text { Type } \\
\text { of } \\
\text { HEIs }\end{array}$ & size & mean & $\begin{array}{c}\text { Std. } \\
\text { deviation }\end{array}$ & $\begin{array}{c}\mathrm{t}- \\
\text { value }\end{array}$ & $\begin{array}{c}\mathrm{p}- \\
\text { value }\end{array}$ \\
\hline $\begin{array}{c}\text { private } \\
\text { govt. }\end{array}$ & 134 & 4.3731 & 0.61047 & 1.161 & 0.247 \\
\hline
\end{tabular}

Indicates significance at $5 \%$ level Since $\mathrm{p}$ value is $>0.05$, the null hypothesis is accepted $5 \%$ significance level. Hence we conclude that, there is no significant difference between the Knowledge creating practices in private \& public higher education institution.

Knowledge capturing

Table 9: Results Of Independent Sample T Test- Knowledge Capturing

\begin{tabular}{|c|c|c|c|c|c|}
\hline $\begin{array}{c}\text { Type } \\
\text { of } \\
\text { HEIs }\end{array}$ & size & mean & $\begin{array}{c}\text { Std. } \\
\text { deviation }\end{array}$ & $\begin{array}{c}\mathrm{t}- \\
\text { value }\end{array}$ & $\begin{array}{c}\mathrm{p}- \\
\text { value }\end{array}$ \\
\hline $\begin{array}{c}\text { private } \\
\text { govt. }\end{array}$ & 134 & 4.1810 & 0.59240 & 0.420 & 0.675 \\
\hline
\end{tabular}

Indicates significance at 5\% level Since $\mathrm{p}$ value is $>0.05$, the null hypothesis is accepted $5 \%$ significance level. Hence we calculate that, there is no significant difference between the Knowledge capturing practices in private $\&$ public higher education institution.

\section{Knowledge organizing}

Table 10: Results Of Independent Sample T Test- Knowledge Organizing

\begin{tabular}{|c|c|c|c|c|c|}
\hline $\begin{array}{c}\text { Type } \\
\text { of } \\
\text { HEIs }\end{array}$ & size & mean & $\begin{array}{c}\text { Std. } \\
\text { deviation }\end{array}$ & $\begin{array}{c}\mathrm{t}- \\
\text { value }\end{array}$ & $\begin{array}{c}\mathrm{p}- \\
\text { value }\end{array}$ \\
\hline
\end{tabular}


The Practice of Knowledge Management Processes- A Comparative Study of Public and....

\begin{tabular}{|c|c|c|c|c|c|}
\hline $\begin{array}{c}\text { private } \\
\text { govt. }\end{array}$ & 134 & 3.9328 & 0.60942 & - & 0.403 \\
\hline
\end{tabular}

Indicates significance at 5\% level Since $\mathrm{p}$ value is $>0.05$, the null hypothesis is accepted $5 \%$ significance level. Hence we calculate that, there is no significant difference between the Knowledge organizing practices in private \& public higher education institution.

\section{Knowledge storing}

\section{Table 11: Results Of Independent Sample T Test- Knowledge Storing}

\begin{tabular}{|c|c|c|c|c|c|}
\hline $\begin{array}{c}\text { Type } \\
\text { of } \\
\text { HEIs }\end{array}$ & size & mean & $\begin{array}{c}\text { Std. } \\
\text { deviation }\end{array}$ & $\begin{array}{c}\text { t- } \\
\text { value }\end{array}$ & p-value \\
\hline $\begin{array}{c}\text { private } \\
\text { govt. }\end{array}$ & 134 & 3.9496 & 0.62436 & - & $0.000^{* *}$ \\
\hline
\end{tabular}

** Indicates significance at $5 \%$ level Since $\mathrm{p}$ value is $<0.05$, the alternative hypothesis is accepted $1 \%$ significance level. Hence we conclude that, there is a significant difference between the Knowledge storing practices in private \& public higher education institution.

By comparing the mean values of Knowledge storage of Govt. Educational Institutions are more than the Private Institutions. It means that in the sample test the people/faculty/academics of NITK, Surathkal have been updating by storing more number of papers/journal articles in the form of documentation and a total of 12,872 papers have been documented/updated till May, 2014, whereas the people/academics in MIT, Manipal are updating or storing their journal articles in e-print and only a total of 8652 papers have been updated and hence the mean value is found less. It may be the reason that most of the faculty may not be aware of the facility of e-print provided in MIT and the authorities are not motivating the faculty to use the facility that is beneficial to the faculty. Also, it is seen that, knowledge sharing barriers exists in pockets and hence it prevents the faculty from sharing their research work. Hence, we find the decline in Knowledge storage in MIT.

The knowledge storage has its importance only when the members of the HEIs are encouraged to use the facility by providing some incentives. This would not only help the faculty to update knowledge regularly but also gain personally. In fact, this encourages faculty to use the facility effectively and motivate them towards new knowledge creation.

\section{Knowledge disseminating}

Table 12: Results Of Independent Sample T Test- Knowledge Disseminating

$* *$ indicates significance at $5 \%$ level Since $\mathrm{p}$ value is $<0.05$, the alternative hypothesis is accepted 5\% significance level. Hence we calculate that, there is a significant difference between the Knowledge disseminating practices in private \& public higher education institution.

\begin{tabular}{|c|c|c|c|c|c|}
\hline $\begin{array}{c}\text { Type } \\
\text { of } \\
\text { HEIs }\end{array}$ & size & mean & $\begin{array}{c}\text { Std. } \\
\text { deviation }\end{array}$ & $\begin{array}{c}\mathrm{t}- \\
\text { value }\end{array}$ & $\mathrm{p}$-value \\
\hline $\begin{array}{c}\text { Private } \\
\text { govt. }\end{array}$ & 134 & 4.2817 & 0.63824 & - & $0.003 * *$ \\
\hline
\end{tabular}

Knowledge dissemination receives the higher ratings among the academics in the public HEIs. The core activities of the academics that is primarily responsible for generating knowledge through research and disseminating the outputs via teaching and other platforms. The public and the private HEIs have developed their directories of expertise on the Internet and the information is made available on the web site. In many cases, the abstracts of the published papers are featured on the web sites which allow the academics from the similar or different HEIs to cite relevant research works from these sources in their efforts to develop and update the current knowledge. The HEIs have been organising lectures, conferences, teaching-training sessions from time to time for the academics to share their knowledge.

In the Independent Sample T test we find that the mean value (4.4839) is more in the case of NITK, Surathkal and less (4.2817) in the case of MIT, Manipal. This shows that the authorities of NITK are disseminating more knowledge compared to MIT. It may be because NITK is well established in terms of documentation of the Knowledge and the usage of portals and the academics go for proper updating of knowledge. Also, NITK being a Government organisation, gets funding from Government agencies very easily when compared to MIT and hence it has well established R\&D set-ups which facilitate learning and knowledge sharing.

\section{Knowledge application}

Table 13: Results Of Independent Sample T Test- Knowledge Application

\begin{tabular}{|l|l|l|l|l|l|}
\hline $\begin{array}{l}\text { Type } \\
\text { of }\end{array}$ & size & mean & $\begin{array}{l}\text { Std. } \\
\text { deviation }\end{array}$ & $\begin{array}{l}\text { t- } \\
\text { value }\end{array}$ & $\begin{array}{l}\mathrm{p}- \\
\text { value }\end{array}$ \\
\hline
\end{tabular}


The Practice of Knowledge Management Processes- A Comparative Study of Public and....

\begin{tabular}{|l|c|c|c|c|c|}
\hline HEIs & & & & & \\
\hline $\begin{array}{l}\text { private } \\
\text { govt. }\end{array}$ & 134 & 4.0653 & 0.60459 & - & 0 \\
\hline
\end{tabular}

**Indicates significance at $5 \%$ level Since $\mathrm{p}$ value is $>0.05$, the null hypothesis is accepted $5 \%$ significance level. Hence we calculate that, there is no significant difference between the Knowledge application practices in private \& public higher education institution.

\section{KM effectiveness}

\section{Table 14: Results Of Independent Sample T Test- Km Effectiveness}

\begin{tabular}{|c|c|c|c|c|c|}
\hline $\begin{array}{c}\text { Type } \\
\text { of } \\
\text { HEIs }\end{array}$ & size & mean & $\begin{array}{c}\text { Std. } \\
\text { deviation }\end{array}$ & $\begin{array}{c}\mathrm{t}- \\
\text { value }\end{array}$ & $\begin{array}{c}\mathrm{p}- \\
\text { value }\end{array}$ \\
\hline $\begin{array}{c}\text { Private } \\
\text { govt. }\end{array}$ & 134 & 4.3109 & 0.69272 & - & $0.011^{*}$ \\
\hline
\end{tabular}

* Indicates significance at 5\% level Since $\mathrm{p}$ value is $<0.05$, the alternate hypothesis is accepted $5 \%$ significance level. Hence we calculate that, there is a significant difference between the KM effectiveness practices in private \& public higher education institution.

The private and the public HEIs manage the knowledge of the knowledge management in various ways. A better manager of KM will create new knowledge in terms of research by referring to the portals and the academics retrieving the required source of knowledge as per their requirement.

In the results of independent sample T test is clear that the mean value of MIT, Manipal (4.3109) is lesser than NITK, Surathkal (4.5054). Here we find that NITK, Surathkal is a better manager of knowledge management compared to MIT, Manipal. When there is more effective knowledge management in an organisation it is more beneficial to the individuals as well as the HEIs. This leads to good decision making and prepare to face effectively the competition in global level.

\section{Conclusion}

This study contributes towards the advancement of knowledge of the KM processes in the setting of HEIs considering what the present knowledge is lacking in the private and the public HEIs. The findings are supposed to help the HEIs undergo a self-check of the various processes proposed so that some actions can be taken to minimise and bridge the gaps. Besides, it is also expected that the recommendations proposed would provide insights to the HEIs on how to organise their KM processes in the required perspective to be more competitive facing the global challenges.

The implementation of knowledge management is obviously essential for most of the managers since the knowledge has its competitive advantage in all organizations. The organizations may define an appropriate knowledge management system and control it successfully. Thus, the HEIs also be the leading organisations in designing and implementing an appropriate knowledge management system and for this requires the investigation of infrastructures of knowledge management and a practical action to be taken in various stages of knowledge management implementation. The present research has been carried out on the knowledge management process in two public and private HEIs.

\section{References}

[1]. [1]Davenport, T., De Long, D. and Beers, M., "Successful knowledge management projects", Sloan Management Review, Vol. 39, Issue No. 2, 1998, pp. 43-57.

[2]. Gupta, B., L.S. Iyer, and J.E. Aronson, "Knowledge Management: Practices and Challenges," Industrial Management and Data Systems, Vol. 100, Issue No. 1. 2000, pp. 17-21.

[3]. Cheng M.Y, Ho J, S. Y, and Lau P. M. "Knowledge Sharing in Academic Institutions: A Study of Multimedia University Malaysia". Electronic Journal of Knowledge Management, Vol. 7, Issue No.3, pp.313 - 324.

[4]. Joseph, M.F. (2001), "Key Issues in Knowledge Management”, Knowledge and Innovation: Journal of the Knowledge Management Consortium International, Vol. 1, No. 3, 2000, pp. 8-38.

[5]. Mintzberg, H, Structure in Fives: Designing Effective Organisations, (Eaglewood Cliffs, NJ: Prentice-Hall, 1993)

[6]. Nonaka, I., \& Konno, N.(1998). The Concept of" Ba": Building a Foundation for Knowledge Creation. California Management Review, 40 (3): 40-54

[7]. Patrinos, H.A. 1990, "The privatization of higher education in Columbia, effects on quality andequity", Higher Education, Vol. 20 No.2, 1990, pp. 161-73.

[8]. Ramachandran, S. D., Chong, S. C., \& Ismail, H. (2009). The practice of knowledge management processes: A comparative study of public and private higher education institutions in Malaysia. Vine, 39(3), 203-222.

[9]. Skyrme, D.J. and Amidon, D.M. (1997), Creating the Knowledge Based Business, BusinessIntelligence, London.

[10]. Steyn, G.M. (2004), "Harnessing the power of knowledge in higher education”, Higher Education, Vol. 124,Issue No. 4, pp. 61531.

[11]. Tippins, M.J.), "Implementing knowledge management in academia: teaching the teachers", The International Journal of Educational Management, Vol. 17, Issue No. 7, 2003, pp. 339-45.

[12]. Zack,M., Knowledge and Strategy,(Butterworth-Heinmann,1999a).

[13]. Boston, MA. Gupta, B., Lakshmi, S. and Iyer, J.E., "Knowledge management: practices and challenges", Industrial Management \& 
The Practice of Knowledge Management Processes- A Comparative Study of Public and....

[14]. Data Systems, Vol. 100, No. 1, 2000, pp. 17-21. 